is "bound to follow the safer opinion of the priest." Providing a variety of instances, Southwell concludes "a penitent is not suitably disposed if he does not wish to obey a confessor who, for a just and grave reason, wishes the penitent to conform to the demands of his judgment" (51). Southwell lets Trent's famous sacred tribunal of the confessional negate the probable freedom of the penitent, thus leaving us to ask, for whose original benefit was probabilism?

Holmes provides an incomparable volume that helps us understand how the Roman Catholic church in England faced contemporary challenges as it grew in institutional stability. One suspects that as the church grew in freedom, the consciences of its lay members did not.

james f. keenan, sj, Boston College

Onnekink, David and Gijs Rommelse (eds.). Ideology and Foreign Policy in Early Modern Europe (1650-1750). Politics and Culture in Europe, 1650-1750. Burlington, VT: Ashgate, 2011. Pp. xi, 320. ISBN 978-1-4094-1913-6 (hardcover) \$134.95.

Realist international relations (IR) theorists have argued that the Treaty of Westphalia in 1648 ushered in an era of foreign policy decision-making based on raison d'état rather than ideology. Consequently, ideology was all but written from the narrative of European relations in the post-Westphalian period, and political theorists, eager to understand the emergence of "modern" international relations, found few reasons to look for clues in the early modern period. Yet cracks are appearing in the realist edifice as post-structuralist and constructivist theories are applied to the study of foreign policy. David Onnekink and Gijs Rommelse's edited collection is a product of these developments and the first detailed study of ideology and early modern foreign policy. The editors have assembled a group of well-respected scholars, newly-minted PhDs, and accomplished graduate students who challenge the notion that between 1648 and 1789 , foreign policy was merely a "cynical game for power, in which morality or religion, let alone ideology, played no role of importance" (2).

Their introduction suggests that after 1648, the political nation mattered; with the emergence of parties and interest groups in many European countries, 
ideology shaped domestic politics as well as foreign and economic affairs. The debates that played out in the emerging public sphere owed much to the "power of language" (4). In his response to the introduction, Robert von Friedeburg explores how cheap print and the mass market served as "core requirements for the emergence of these 'ideologies"' (11). He stresses that pamphlet wars predated the 1650s and that such "wars" increasingly influenced elites who had a stake in the outcome of the monarch's foreign policy.

Twelve chapters organized around five broadly-based areas of focus follow the introduction and response. The first three chapters examine late Stuart and Hanoverian England, investigating the influence of Whig and Tory pamphlets and histories on English foreign policy. Steven Pincus explores the impact of Robert Molesworth's An Account of Denmark (1693) on political discourse after the Glorious Revolution, arguing that the work, which was widely read inside and outside of Britain, was a Whig polemic supporting William III's Grand Alliance and denouncing the blue-water policy. Gary Evans examines half a century of Whig and Tory histories and finds that "partisan politics profoundly affected the nature of historicity" (56), with authors of both parties equally adept at using past events to comment on contemporary foreign policy. Doohwan Ahn also draws on the importance of historical analogies, citing the Athenian Empire as a popular example used-by the likes of Swift, Davenant, Hume, and Bolingbroke-to argue for or against continental commitments and the costs and direction of empire, while dancing delicately around the issue of Athenian democracy.

Chapters 4 through 8 concentrate on ideological debates and extend the scope of the discussion further afield. Onnekink's study of ideology and the Anglo-Dutch War of 1672 contends that the struggle between the Orangist and Loevestein parties was inextricably linked to wider international developments. He argues that Charles II had a "pro-Orange bias" and was eager to see the Loevestein faction removed. While war brought about these desired ends, it failed to secure English control over the Prince of Orange. Stéphane Jettot charts the problems English diplomats had in juggling a "gamut of interests" in negotiations with foreign governments. He offers up a cautionary note that while official documents suggest harmony in the formulation of foreign policy, rival interests led to disharmony, with diplomats likely to lose both status and fortune for supporting the wrong party. 
Benedict Wagner-Rudell and Solange Rameix then argue that religionthe "eternal interest"-remained influential in European foreign policy long after 1648. Wagner-Rudell examines confessional strife in Poland-Lithuania, noting that the szlachta increasingly based their own notions of liberty on their position as defenders of Catholicism against the slavery they associated with Protestantism and their Swedish and German rivals. What is fascinating is that these same nobles sought to avoid war when they recognized it was not in the best interest of the commonwealth. Ramiex details the use of sermons and the pulpit in France and England to broadcast war propaganda during the Nine Years War, and while she finds distinct differences between the audiences for printed sermons and the speed and methods of publication, she identifies similarities between William and Louis's reliance on preachers to justify their war aims in the name of God.

The final chapters consider various economic interests and the emerging language of balance of power. Henk van Nirop's engaging study of Dutch artist Romeyn de Hooghe offers ample evidence of the power of images in support of Orangist foreign policy. Van Nirop makes the case that ideology, not profit, drove much of the artist's work. On the other hand, Ana Crespo Solana and Gijs Rommelse both find strong connections between profit and ideology in their studies of Spain and Anglo-Dutch relations, respectively. Solana reveals that court parties vied over the direction of imperial commerce, with Hapsburgs backers holding on to the exclusivist model, and Bourbons promoting a hybrid model with greater private participation alongside that of the state. Rommelse finds commerce to be central to the first two Anglo-Dutch wars but sees the last free of such motivations. He suggests that mercantile ideology was tied closely to the republic's raison d'être and to the growing influence of the New London merchants in Commonwealth and Restoration England. Lastly, Andrew C. Thompson holds that the language of balance of power was present in Hanoverian England, with proponents believing that Britain could act as a "balancer" to offset the possibility of a continental universal monarchy. Likewise, Wout Troost asserts that though "balance of power" and "containment" were not part of William III's lexicon, his attempts to undermine the establishment of a universal monarchy of Louis XIV suggest that the concepts were very much a part of his thinking. The editors point out that while these are initial forays, there is little doubt that diplomatic historians and political 
scientists will find the cultural approach used-and conclusions reached-to be very worthy of future debate and investigation.

David R. LaWrence, Glendon College, York University

\section{Popper, Nicholas.}

Walter Ralegh's History of the World and the Historical Culture of the Late Renaissance.

Chicago and London: University of Chicago Press, 2012. Pp. xv, $350+19$ ill. ISBN 978-0-2266-7500-8 (hardcover) \$55.

There is little doubt that Sir Walter Ralegh looms large in the history of late Elizabethan and early Stuart England. He has come to be regarded as a gallant courtier, brave soldier, swashbuckling privateer, and adventurous explorer who disobeyed James I and lost his head for having done so. Of course, Ralegh was also a man of learning, a scholar and historian who authored the 1,500-folio History of the World - a fact sometimes overlooked when set against his long list of impressive and rather more exciting accomplishments. However, in this superb study of Ralegh's History which appears on the eve of the quadricentennial of its publication, Nicholas Popper has shed new light not only on the crafting of the book, but also on what its contents and sources reveal about Ralegh's place in the intellectual community of early modern Europe. As Popper sees it, Ralegh must be viewed as an active participant in "a venerable, vibrant culture of politics, polemic and erudition" (6), whose magnum opus was to serve not only in his own rehabilitation but also in charting the course for future counsellors of kings and princes.

Popper's book is divided into six well-balanced thematic chapters and a conclusion. Extensive notes, many of which are Latin quotations from Ralegh's sources, are augmented by a lengthy bibliography that will surely serve students of Raleghana well in years to come. The book is both a rich textual analysis of the History and a study of the work's impact and readership. The first chapter, "Context," offers an overview of Ralegh's attempts to establish his position as a courtier capable of providing good counsel. Popper does not see the History as being "too sawcie in censuring of Princes" as James I did, but instead views the 